\title{
ANALISIS KESULITAN SISWA SMP DALAM MEMAHAMI KONSEP KUBUS BALOK
}

\author{
Maryanih $^{1}$, M. Afrilianto ${ }^{2}$, Euis Eti Rohaeti ${ }^{3}$ \\ 1, 2, 3IKIP Siliwangi, J1. Terusan Jendral Sudirman Cimahi 4052 \\ ${ }^{1}$ mmaryanihnurulyazmin@yahoo.com, \\ 2muhammadafrilianto@ikipsiliwangi.ac.id,3e2rht@ikipsiliwangi.ac.id
}

\begin{abstract}
The descriptive research aims to diagnose the difficulties of secondary school students in understanding Cube and Rectangular Prism. Geometry test and interview are used as the instrument. The subjects are 3 seventh grade students who respectively represent high, medium and low ability in mathematics. This research finds that the students have difficulties in understanding the properties of cube and rectangular prism, inventing the surface area, and using the formula to determine the surface area. The difficulty in using the formula to solve related problems is an effect of memorizing ready-made formula without understanding so the students are easy to forget it. The alternative ways to cope with the difficulties are: (a) Using computer application (PowerPoint, Ms Word with SmarArt Graphic) and other current softwares like Cabri Geometry, The Geometer's Sketchpad (GSP), Geometry Expert, Logo, Geogebra, and Wingeom; (b) Activating students' prior knowledge about plane which explains the side of the solid figures; (c) Implementing guided discovery learning with students' worksheet; and (d) giving variative exercises involving contextual or non-contextual problems.
\end{abstract}

Keywords: Mathematical Understanding, Cube Prism

\begin{abstract}
Abstrak
Penelitian ini bertujuan untuk mendiagnosis kesulitan belajar siswa SMP dalam memahami materi kubus balok. Jenis penelitian ini adalah penelitian deskriptif dengan pendekatan kualitatif. Instrumen yang digunakan adalah tes geometri dan wawancara. Hasil penelitian ini menunjukkan bahwa siswa mengalami kesulitan dalam menguasai konsep kubus dan balok, menemukan rumus luas permukaan kubus balok, dan menggunakan rumus luas permukaan kubus dan balok. Kesulitan menggunakan rumus pada penyelesaian soal sebagai akibat dari menghafal rumus siap pakai, sehingga siswa sering lupa dengan rumus. Alternatif pemecahan kesulitan belajar siswa tersebut, yaitu: (a) Menggunakan aplikasi komputer (Power point, Ms Word dengan SmartArt Graphic) dan software seperti Cabri Geometry, The Geometer's Sketchpad (GSP), Geometry Expert, Logo, Geogebra, dan Wingeom; (b) Mengaktifkan dengan baik materi prasyarat tentang bangun datar yang menjelaskan sisi-sisi pada bangun ruang; (c) Menerapkan metode penemuan terbimbing menggunakan LKS terbimbing; dan (d) memperbanyak mengerjakan latihan soal baik yang bersifat kontekstual maupun soal-soal yang bersifat non-kontekstual.
\end{abstract}

Kata Kunci: Analisis; Kesulitan; Pemahaman; Kubus Balok

How to cite: Maryanih,A., Afrilianto, M., \& Rohaeti, E.E. (2018). Analisis Kesulitan Siswa SMP dalam Memahami Konsep Kubus Balok. JPMI - Jurnal Pembelajaran Matematika Inovatif, 1 (4), 751-758

\section{PENDAHULUAN}

Objek kajian matematika berupa fakta, konsep, operasi dan prinsip bersifat abstrak. Dalam pembelajaran, perlu ada kesesuaian objek yang dipelajari. Siswa tidak hanya mampu melakukan perhitungan, tetapi juga memahami konsep matematika agar pembelajaran matematika menjadi bermakna. Siswa tidak hanya sekedar menghafal rumus dan 
menggunakannya untuk mencari hasil. Keabstrakan matematika semakin bisa dipahami dengan memperkaya dan menghubungkan konsep-konsep yang beraneka ragam. Seperti halnya dalam mempelajari kubus dan balok, siswa tidak dapat menjelaskan keabstrakan kubus dan balok jika siswa hanya dijelaskan definisi-definisi tanpa menunjukkan bendanya secara langsung. Objek-objek yang dipelajari memang ada yang mudah dan sulit, namun (Mulyanti, Yani, \& Amelia, 2018) menegaskan bahwa siswa akan mudah mempelajari matematika, apabila siswa telah mengetahui konsep dengan baik.

Dalam pembelajaran di kelas, objek matematika tersebut dirasakan sulit untuk dipelajari siswa apalagi dalam pemahaman konsep. Hal ini disebabkan karena dalam proses belajar matematika, siswa sering dihadapkan dengan rumus sementara matematika membutuhkan keterkaitan antara objek-objeknya. Matematika juga membutuhkan penalaran yang logis dalam menyelesaikan beberapa bentuk soal cerita dan konsep. Artinya, bahwa dalam penyelesaian soal-soal matematika tidak hanya membutuhkan hasil, akan tetapi proses berpikir siswa dalam menyelesaikannya sehingga matematika bukan hanya tentang hasil tetapi juga proses yaitu penalaran logis.

Siswa dapat menerima materi dan menyelesaikan soal-soal tapi tidak dapat menjadikannya bermakna. Bermakna di sini maksudnya adalah siswa dapat menguasai materi tidak hanya untuk menjawab soal akan tetapi dapat menyelesaikan masalah lainnya di luar konteks soal tersebut. Misalnya, jika diberikan soal yang berbeda bentuknya atau diberikan tingkat soal yang lebih sulit, siswa juga dapat menyelesaikannya, namun kenyataannya siswa seringkali masih merasa kesulitan dan akhirnya menyerah jika tidak dapat mengerjakannya. Hal ini disebabkan karena tidak memahami konsep yang dipelajari sehingga menjadi lupa dan kesulitan. Kesulitan ini akan mempengaruhi proses belajar siswa seperti membuat kesalahan dalam menyelesaikan masalah matematika dan hasil belajarnya (Nurainah, Maryanasari, \& Nurfauziah, 2018) Saat ini, hasil belajar matematika siswa masih belum memenuhi harapan, hal ini dapat dilihat dari hasil Ujian Nasional yang dianggap dapat mewakili hasil belajar siswa selama belajar di sekolah. Diketahui rata-rata Ujian Nasional Matematika siswa masih rendah yaitu 5,26 seperti yang ditunjukkan pada tabel berikut.

Tabel 1. Nilai Ujian Nasional

\begin{tabular}{clllll}
\hline No & Uraian & $\begin{array}{l}\text { Bahasa } \\
\text { Indonesia }\end{array}$ & $\begin{array}{l}\text { Bahasa } \\
\text { Inggris }\end{array}$ & Matematika & IPA \\
\hline 1 & $\begin{array}{l}\text { Nilai } \\
\text { tertinggi }\end{array}$ & 9,20 & 8,40 & 8,25 & 9,25 \\
2 & $\begin{array}{l}\text { Nilai } \\
\text { terendah }\end{array}$ & 3,60 & 2,60 & 2,75 & 4,00 \\
Sumber: Data Ujian Nasional SMP 03 Karangpandan & & & 6,79 \\
\hline
\end{tabular}

Hampir setiap tahun, guru dan siswa mengeluhkan hasil belajar matematika tersebut sehingga anggapan sebagian besar siswa mengenai matematika sebagai mata pelajaran yang sulit masih tidak bisa terlepaskan. Di lain pihak, guru juga merasa kesulitan saat menyampaikan materi, siswa menerima materi yang diajarkan tetapi belum tentu mampu mengerjakan persoalan matematika. Apalagi materi ajar yang diberikan berhubungan dengan materi yang objeknya abstrak seperti geometri. 
Menurut (Hudanagara \& Anita, 2018), objek geometri bersifat abstrak. Hal ini tampak jelas pada pendapatnya tentang titik, garis, bidang, dan ruang yang menjelaskan bahwa geometri merupakan salah satu cabang matematika yang bersifat abstrak yang membicarakan titik, garis, bidang, ruang dan keterkaitan satu sama lainnya. Mempelajari geometri dapat menumbuhkan dan mengembangkan kemampuan berfikir logis siswa, namun pada kenyataannya geometri menempati posisi yang memprihatinkan di antara cabang matematika lainnya yang dipelajari di SMP seperti aljabar dan aritmetika. Data dari guru yang mengajar matematika di SMP Negeri 3 Karangpandan berikut menunjukkan hasil belajar siswa untuk geometri, aljabar, dan aritmetika :

Tabel 2. Nilai Rata-rata Pencapaian Siswa Pada Akhir Pokok Bahasan

\begin{tabular}{ccc}
\hline No & Matematika SMP & Nilai rata-rata \\
\hline 1. & Aljabar & 44 \\
2. & Aritmetika & 56 \\
3. & Geometri kelas VIII & 42 \\
4. & Geometri Kelas VII & 53 \\
\hline
\end{tabular}

Pada tabel 2 terlihat perbedaan nilai rata-rata pencapaian materi geometri siswa di kelas VII dan VIII. Nilai rata-rata yang diperoleh siswa pada materi pokok bangun datar lebih tinggi daripada materi bangun ruang yang dipelajari di kelas VIII. Perbedaan ini setidaknya memberikan informasi bahwa pembelajaran geometri di kelas VII lebih baik dibandingkan dengan pembelajaran geometri di kelas VIII. Hal ini menyebabkan penulis memilih menganalisis kesulitan siswa pada geometri ruang di kelas VIII. Selaras dengan hal tersebut, berdasarkan keterangan guru yang mengajar di kelas VIII tersebut juga menjelaskan bahwa siswa merasa lemah di geometri ruang disebabkan siswa mengalami kesulitan saat mempelajari konsep-konsep bangun ruang seperti kubus dan balok yang memiliki titik, bidang, ruang, dan hubungan di antaranya. Kesulitan tersebut, misalnya: 1) Siswa belum dapat menentukan unsur-unsur kubus dan balok seperti titik sudut, rusuk, dan lainnya; 2) Siswa masih menyamakan istilah sisi pada bangun datar dengan bidang sisi pada bangun ruang; 3) Siswa belum bisa membedakan bidang diagonal dan diagonal ruang; 4) Siswa belum dapat menjelaskan bidang diagonal itu bentuknya seperti bangun datar apa, ada yang menyebutkan jajar genjang padahal bentuknya persegi panjang. Jika kesulitan belajar ini tidak dianalisis lebih lanjut akan dapat menyebabkan pemahaman yang kurang sempurna terhadap konsep-konsep geometri selanjutnya yaitu geometri di kelas IX dan di jenjang yang lebih tinggi seperti Sekolah Menengah Atas (SMA) hingga Perguruan Tinggi.

Sementara itu, hasil evaluasi Programme for International Student Assessment (PISA) prestasi belajar matematika di Indonesia untuk siswa usia 13 tahun masih rendah. Pada PISA tahun 2006, Indonesia berada pada peringkat 50 dari 57 negara dengan rerata skor 391 (OECD, 2007). Soal-soal matematika dalam studi PISA lebih banyak mengukur kemampuan menalar, memecahkan masalah dan berargumentasi daripada soal-soal yang mengukur kemampuan teknis baku yang berkaitan dengan ingatan dan perhitungan semata. Rendahnya kemampuan siswa dalam menyelesaikan permasalahan matematika akan mempengaruhi penyelesaian masalah geometri, dan pada umumnya siswa di sekolah menengah mengalami kesulitan dalam mempelajarinya (SUSANTI, 2017)

Adapun (Setiawan \& Susanto, 2011) juga pernah melakukan penelitian yang hampir sama dengan penelitian ini yaitu menganalisis kesalahan mahasiswa dalam menyelesaikan soal geometri analitik bidang materi garis dan lingkaran. Hasil penelitian tersebut menunjukkan bahwa kesalahan mahasiswa dalam menyelesaikan soal geometri analitik materi garis dan 
lingkaran adalah kesalahan konsep, kesalahan hitung, dan kesalahan sistematik. Perbedaannya dengan penelitian ini adalah objek materi yang diteliti yaitu kubus dan balok sedangkan penelitian yang dilakukan oleh Imswatama dan Muhassanah membahas garis dan lingkaran.

Berdasarkan beberapa permasalahan di atas, maka dapat dirumuskan masalah dalam penelitian ini, yaitu: Kesulitan belajar apa saja yang dialami siswa dalam memahami konsep kubus balok dan apa saja alternatif pemecahannya? Penelitian ini bertujuan untuk mendiagnosis kesulitan belajar siswa SMP pada pokok bahasan kubus balok dan menemukan alternatif pemecahannya.

\section{METODE}

Jenis penelitian ini adalah penelitian deskriptif dengan pendekatan kualitatif. Adapun subjek penelitiannya adalah siswa kelas VIII SMP Negeri 3 Karang Pandan. Subjek dalam penelitian ini adalah tiga orang siswa yang masing-masing memiliki kemampuan tinggi, sedang, dan rendah. Alasan pemilihan 3 subjek tersebut adalah untuk merepresentasikan masingmasing tingkatan kemampuan siswa dan sebagai pembanding antara siswa satu dengan yang lainnya. Informasi mengenai tingkat kemampuan siswa ini, penulis dapatkan melalui wawancara dengan guru matematika yang mengajar di kelas VIII. Guru matematika tersebut lebih mengetahui tingkat kemampuan siswanya sehari-hari dalam proses pembelajaran yang didukung dengan nilai ulangan harian matematika pada pokok bahasan kubus dan balok serta nilai ulangan semester terakhir yang terangkum dalam Tabel 3 berikut

Tabel 3. Nilai Ulangan Harian dan Semester Matematika Siswa Kelas VIII

\begin{tabular}{cccc}
\hline No & $\begin{array}{c}\text { Subjek } \\
\text { Penelitian }\end{array}$ & Nilai Ul. Harian kubus dan balok & $\begin{array}{c}\text { Nilai Ulangan } \\
\text { Semester }\end{array}$ \\
\hline 1. & C & 80 & 75 \\
2. & B & 65 & 64 \\
3. & A & 52 & 50 \\
\hline
\end{tabular}

Keterangan:

Subjek $\mathrm{C}=$ kemampuan tinggi

Subjek $\mathrm{A}=$ kemampuan rendah

Subjek B = kemampuan sedang

Instrumen yang digunakan dalam penelitian ini adalah tes geometri dan wawancara. Tes geometri merupakan tes tertulis yang dirancang untuk mengidentifikasi kesulitan yang dialami siswa dalam menyelesaikan persoalan geometri khususnya kubus dan balok. Estenberg (2002) mendefinisikan wawancara sebagai pertemuan dua orang untuk bertukar informasi dan ide melalui tanya jawab sehingga dapat dikonstruksikan makna dalam suatu topik tertentu. Wawancara dirancang untuk mempermudah penulis dalam menggali informasi mengenai kesulitan belajar siswa pada tes geometri yang diberikan dalam memahami konsep kubus dan balok. Adapun jenis wawancara yang digunakan dalam penelitian ini adalah wawancara tak terstruktur (unstructured interview). Menurut Sugiyono (2016) wawancara tidak terstruktur merupakan wawancara yang bebas di mana peneliti tidak menggunakan pedoman wawancara yang telah tersusun secara sistematis dan lengkap untuk pengumpulan datanya. Analisis data dilakukan dengan cara membandingkan data hasil tes geometri dengan data hasil wawancara. 


\section{HASIL DAN PEMBAHASAN}

Untuk mengetahui letak kesulitan siswa dalam pemahaman konsep dapat ditentukan dari kesalahan-kesalahan siswa dalam menuliskan setiap langkah kerjanya dalam menyelesaikan masalah matematika. Berikut contoh hasil kerja siswa yang melakukan kesalahan:

Soal No. 1

Gambarkanlah sebuah kubus $A B C D . E F G H$ dan sebutkan unsurunsur yang dimilikinya! Berdasarkan unsur-unsur yang dimiliki kubus tersebut, coba jelaskan pengertian dari kubus!

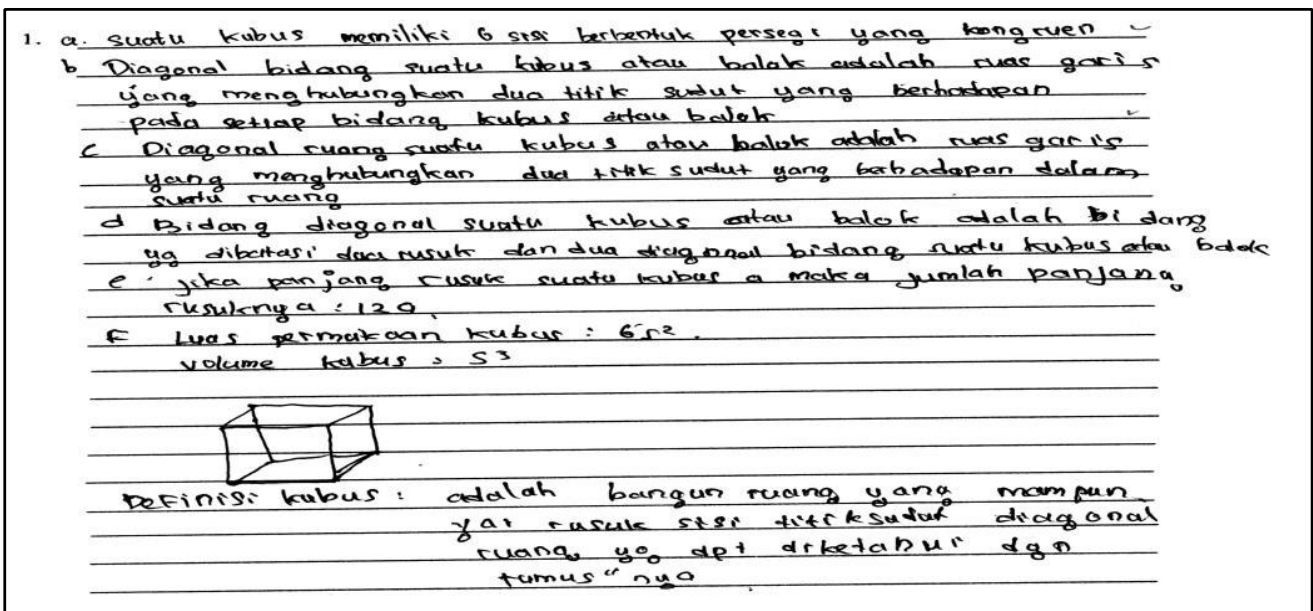

Gambar 1 . Jawaban Subjek A untuk Soal No. 1

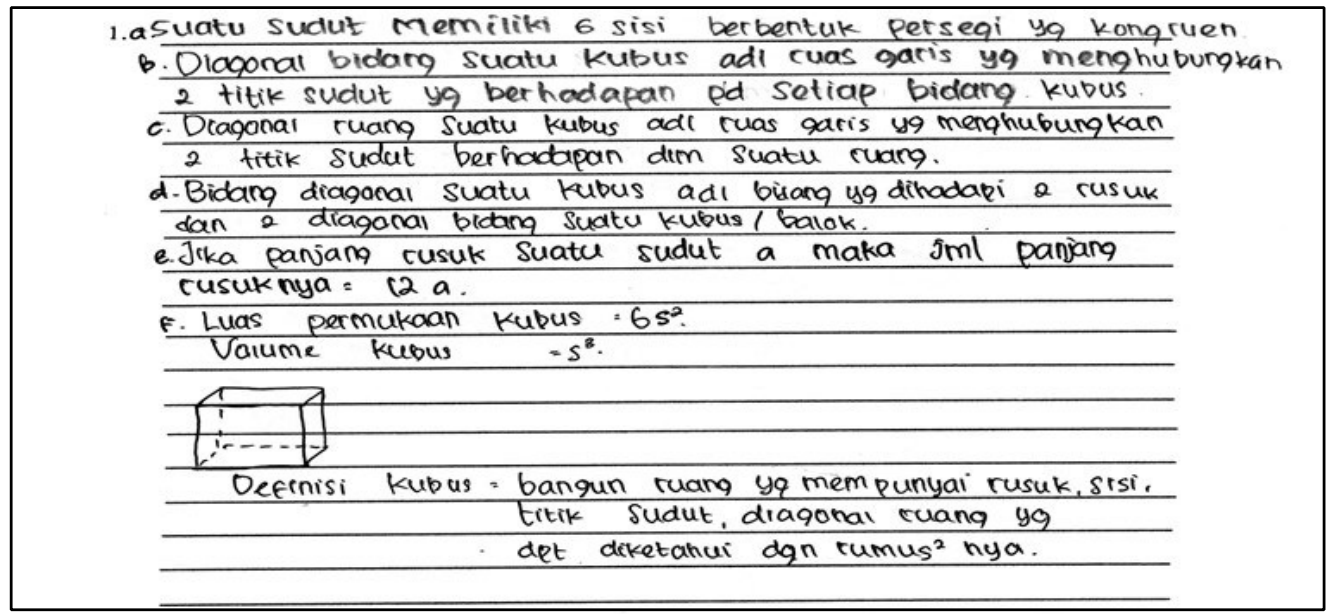

Gambar 2 . Jawaban Subjek B untuk Soal No. 1

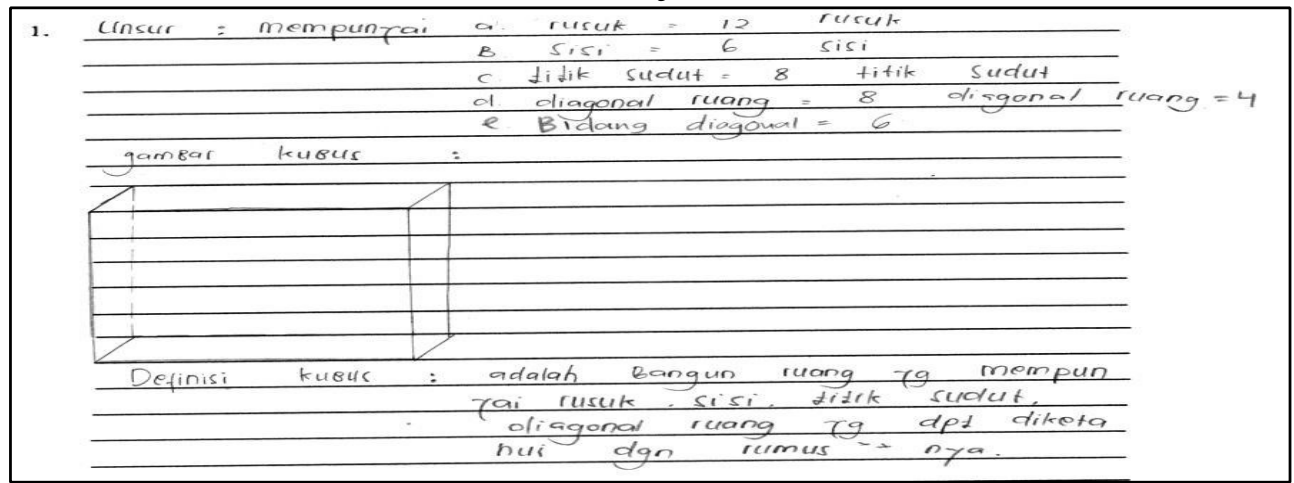

Gambar 3. Jawaban Subiek C untuk Soal No. 1 
Berdasarkan hasil kerja siswa di atas (Gambar 1-3), subjek A belum mampu menuliskan semua unsur-unsur kubus, hanya beberapa saja yang bisa disebutkan, belum memahami soal, dan dalam mendefinisikan kubus masih terkesan bersifat teks atau hafalan atau bukan karena benar-benar memahami konsep. Subjek B juga melakukan kesalahan yang sama dengan subjek A. Subjek C sudah dapat menuliskan unsur-unsur kubus dan jumlahnya. Namun, masih terdapat kesalahan pada diagonal bidang, subjek $\mathrm{C}$ menuliskan jumlah diagonal ruang ada 8 dan 4 sehingga tidak jelas yang mana dimaksud dengan diagonal ruang. Selain itu, semua subjek juga belum bisa menunjukkan unsur-unsur pada gambar. Selain itu, terdapat juga kesulitan membedakan konsep sisi pada bangun datar dan bidang sisi pada bangun ruang. Siswa masih keliru dalam menggunakannya. Siswa menggunakan istilah "sisi" pada kubus bukan "bidang sisi". Hal ini disebabkan karena siswa masih menyamakan konsep sisi pada bangun datar dengan bangun ruang. Kemudian, kesulitan selanjutnya adalah kesulitan mendefinisikan kubus dan balok.

Menurut Sumardyono (2004), konsep adalah idea abstrak yang dapat digunakan untuk menggolongkan atau mengkategorikan sekumpulan objek, apakah objek tertentu merupakan contoh konsep atau bukan. Konsep dapat dipelajari lewat definisi atau observasi langsung. Siswa telah dianggap memahami konsep bila ia dapat memisahkan contoh konsep dari yang bukan contoh konsep.

\section{Kesulitan menemukan rumus}

Adapun kesulitan menemukan rumus meliputi kesulitan menemukan rumus luas permukaan kubus dan balok. Kesulitan ini dapat ditemukan saat melihat kesalahan siswa dalam mengerjakan soal nomor 3 yaitu menemukan rumus luas permukaan kubus. Tidak ada satu langkah pengerjaan pun yang bisa dilakukan siswa. Hal ini disebabkan karena siswa tidak mengerti dan tidak terbiasa dengan masalah seperti itu. Siswa terbiasa menggunakan rumus "siap pakai" untuk penyelesaian soal. Begitu juga dalam menemukan rumus luas permukaan balok, subjek tidak dapat menemukan rumus luas permukaan balok berdasarkan jaringjaring balok yang telah diketahui. Padahal sebuah rumus luas permukaan kubus atau balok dapat dipahami melalui sebuah jaring-jaring tersebut.

\section{Kesulitan menggunakan rumus}

Adapun kesulitan penggunaan rumus meliputi kesulitan penggunaan rumus luas permukaan kubus dan balok. Saat menghitung luas permukaan kubus dan balok, Semua subyek penelitian mengalami kesalahan. Siswa menggunakan kembali konsep di kelas VII yaitu $L=$ sisi $x$ sisi, padahal itu rumus luas persegi dan bukan kubus. Ketika diwawancarai, siswa menjawab masih terbawa dengan konsep bangun datar di kelas VII dan ada juga yang menjawab lupa. Begitu juga dengan balok, dalam penyelesaian soal yang melibatkan rumus dan perhitungan, siswa belum dapat membedakan rumus volume balok dan luas permukaan balok.

\section{KESIMPULAN}

Berdasarkan analisis tes dan wawancara mengenai kesulitan belajar siswa pada materi kubus dan balok dapat disimpulkan kesulitan siswa meliputi: (a) Kesulitan menguasai konsep kubus dan balok yang terdiri dari kesulitan menyebutkan dan menunjukkan unsur-unsur kubus dan balok pada gambar, kesulitan membedakan konsep sisi pada bangun datar dan bidang sisi pada bangun ruang, dan kesulitan memberikan pengertian kubus dan balok. (b) Kesulitan menemukan rumus luas permukaan kubus dan balok. (c) Kesulitan menggunakan rumus luas permukaan kubus dan balok. Alternatif pemecahan dari kesulitan belajar siswa 
tersebut, yaitu: (a) Untuk mengatasi kurangnya penguasaan konsep kubus dan balok dapat menggunakan alat peraga sederhana dan aplikasi komputer dan software seperti Cabri Geometry (Cabri I dan Cabri II), The Geometer's Sketchpad (GSP), Geometry Expert, Logo, Geogebra, dan Wingeom. Dengan menggunakan alternatif ini diharapkan siswa dapat lebih mudah memahami konsep bangun ruang karena diberikan penyajian secara visualisasi dimana unsur-unsur kubus dan balok dijelaskan secara konkret melalui gerakan gambar sehingga siswa tidak berimajinasi lagi dengan bentuk-bentuk unsur kubus dan balok tersebut. Guru juga dapat mengingatkan kembali siswa pada materi persegi dan persegi panjang terlebih dahulu, kemudian menghubungkan pemahaman konsep geometri yang didapatkan pada materi prasyarat dengan kubus dan balok yang dipelajari sekarang untuk mengatasi kesulitan dalam membedakan konsep sisi pada bangun datar dan bidang sisi pada bangun ruang. Untuk mengatasi kesulitan siswa dalam mendefinisikan kubus dan balok dapat dilakukan dengan membuat siswa memahami unsur-unsurnya terlebih dahulu, kemudian membimbing siswa untuk dapat mengungkapkan pengertian kubus dan balok secara tertulis dengan kata-katanya sendiri berdasarkan konsep yang dimilikinya. (b) Kesulitan siswa dalam menemukan rumus dapat diupayakan dengan menerapkan metode penemuan terbimbing yaitu menggunakan LKS terbimbing. (c) Kesulitan siswa pada penggunaan rumus dapat diupayakan dengan memperbanyak mengerjakan latihan soal yang bervariasi baik bersifat kontekstual maupun non kontekstual.

\section{DAFTAR PUSTAKA}

Hudanagara, M. A., \& Anita, I. W. (2018). Analisis Kesulitan Yang Dialami Siswa Smp Pada Kemampuan Berpikir Kreatif Matematis Pokok Bahasan Segitiga Dan Segiempat. Silogisme, 3(1), 14-20.

Mulyanti, N. R., Yani, N., \& Amelia, R. (2018). Analisis Kesulitan Siswa Dalam Pemecahan Masalah Matematik Siswa Smp Pada Materi Teorema Phytagoras. Jpmi (Jurnal Pembelajaran Matematika Inovatif), 1(3), 415-426.

Nurainah, N., Maryanasari, R., \& Nurfauziah, P. (2018). Analisis Kesulitan Kemampuan Koneksi Matematis Siwa Smp Kelas Viii Pada Materi Bangun Datar. Jpmi (Jurnal Pembelajaran Matematika Inovatif), 1(1), 61-68.

Setiawan, A., \& Susanto, B. (2011). Studi Simulasi Tentang Penerapan Grafik Pengendali Berdasarkan Analisis Komponen Utama (Principal Component Analysis).

Susanti, R. (2017). Analisis Kesalahan Pemahaman Konsep Bangun Datar Pada Siswa Kelas V Min Sukosewu Gandusari Blitar. 
